\title{
希ガス脱ガスモデルに基づく金星・火星の火成活動史
}

\author{
東京大学理学系地質学専攻* 佐々木 晶・田 近 英一

\section{Evolution of Volcanic Activities on Venus and Mars from Noble Gas Degassing Models}

\author{
Sho Sasaki and Eiichi Tajika \\ Geological Institute, School of Science, University of Tokyo Bunkyo-ku, Tokyo 113 Japan \\ (Received April 19, 1994; Accepted July 18, 1994)
}

\begin{abstract}
Radiogenic noble gas data provide valuable information on planetary evolution through their degassing histories. The relative abundance of ${ }^{40} \mathrm{Ar}$ in the Cytherean atmosphere is 0.26 of that in the Earth's atmosphere. Calculation of a ${ }^{40} \mathrm{Ar}$ degassing model along with mantle evolution and melt migration shows that the average magma production rate on Venus is about $5 \mathrm{~km}^{3} / \mathrm{yr}$. Duration of plate motion on Venus, if existed, would be less than several hundred million years. For Mars, estimated volume of erupted volcanic materials is compatible with the present Martian ${ }^{40} \mathrm{Ar}$, which is about $1 / 20$ of ${ }^{40} \mathrm{Ar}$ in the Earth's atmosphere. On the other hand, early degassing fraction estimated from Martian radiogenic ${ }^{129} \mathrm{Xe}$ is as much as $1 / 3$ of that of the Earth. This early degassing may be due to the magma ocean cooling. Detection of Martian ${ }^{4} \mathrm{He}$ will be evidence of current degassing activity on Mars. Abundant ${ }^{4} \mathrm{He}$ in Venus atmosphere, showing much longer residence time than the Earth's ${ }^{4} \mathrm{He}$, should correspond to current absence of magnetic field.
\end{abstract}

Key words: Planetary evolution, Mars, Venus, Noble gas, Degassing.

\section{§1.はじめに}

地球型惑星の大気は, 固体惑星内部からの二次的な脱 ガスによって形成されたものであると考えられている [BROWN (1952)]. 惑星の脱ガス史は, 大きく二つのモー ドに分類できるであろう。一つは惑星形成期におけるカ タストロフィックな脱ガス（初期脱ガス）であり，あう 一つは惑星形成後の惑星史に渡るような連続的（あるい は間欠的）な脱ガスである. 脱ガスの具体的なメカニズ ムとして，前者は微惑星衝突による高温高圧状態の発生 に伴う衝突脱ガス [LANGE and Ahrens (1982a, b)]やマ グマオーシャンからの脱ガス, 後者はホットスポットや 中央海嶺などにおけるマグマの生成之噴出（すなわち火 成活動）に伴う脱ガス [RUBEy (1951)]が考えられる. 惑 星大気の形成や進化は，したがって，固体惑星自体の形 成や進化と密接な関係を持っている.

惑星大気において, 希ガス ( $\mathrm{He}, \mathrm{Ne}, \mathrm{Ar}, \mathrm{Kr}, \mathrm{Xe})$ は特 に重要な情報を担っている．水や二酸化炭素などに代表 される惑星表層における主要な揮発性物質は一般に反応

* テ113 東京都文京区本郷 7-3-1
性に富み，固体物質に取り込まれたり，物質循環を行 なったり, あるいは相変化をするために, 大気中の存在 度が必ずしも各惑星の脱ガス史を反映していない．とこ ろが，希ガスは反応性の低い元素であるため, 大気中の 存在度は各惑星の脱ガス史をかなりの程度反映している とみなすことができる（ただし， He は質量が軽いため に惑星大気からの散逸効果を無視できないことや, Xe は堆積物などに吸着する性質を持つことなどに注意する 必要がある).

多くの希ガスには，放射壊変により量が時間的に増加 する放射起源同位体と放射壊変の影響を受けない非放射 起源同位体が存在する. 希ガスの放射起源同位体と非放 射起源同位体の存在比は, 初期脱ガスや惑星進化に対す るさらなる情報を提供する，たとえば，Arには ${ }^{36} \mathrm{Ar}$ 之 ${ }^{40} \mathrm{Ar}$ という同位体が存在する。 ${ }^{40} \mathrm{Ar}$ は地球内部におい て ${ }^{40} \mathrm{~K}$ の放射壊変 (半減期 $1.25 \times 10^{9}$ 年) によって生成 された元素であり，したがって現在の大気及び地球内部 における ${ }^{40} \mathrm{Ar} /{ }^{36} \mathrm{Ar}$ の值は脱ガスの規模とタイミング に関する情報を持っていると考えられる．HAMANO and OzIma (1978) は, Ar 同位体比のデータと Ar の脱ガス 
モデルを用いて，地球の脱ガス史の制約を行なった。 そ の結果, あともと固体地球内部に存在した ${ }^{36} \mathrm{Ar}$ は, 地 球形成後 5 億年以内にその $90 \%$ 以上が脱ガスしたと結 論された。 そのような大規模な初期脱ガスが起こらなけ れば，現在観測されるような ${ }^{40} \mathrm{Ar} /{ }^{36} \mathrm{Ar}$ の值（大気= 295.5, 地球内部 $>5,000 ）$ を説明できないのである，同 様な制約はXe の同位体を用いても可能であり，やはり 同様の結論（初期脱ガスは $50 \mathrm{Ma}$ 以内）が得られている [Allègre et al. (1987), Staudacher and Allègre (1982)].このように, 希ガスの同位体を用いることに よって，固体惑星からの脱ガスの程度やそのタイミン グ,さらには各惑星の内部進化について調べることがで きる [TURCotTE and SCHUBERT (1988)].

一方，大気中の ${ }^{40} \mathrm{Ar}$ の量を制約条件に用いることで, 惑星史に渡る火成活動度を推定することが可能である [TAJIKA and MATsui (1993)]. 地球の場合, 脱ガスの大 部分は中央海嶺における海洋底の生産を伴う火成活動に よってもたらされている，そこで，(1) ${ }^{40} \mathrm{~K}$ の放射壊変に よる ${ }^{40} \mathrm{Ar}$ の生成, (2) マントル物質の断熱上昇によるメ ルトの生成, (3) メルト生成による ${ }^{40} \mathrm{Ar}$ 及び ${ }^{40} \mathrm{~K}$ の固液一気相分配，(4) マグマ噴出に伴う ${ }^{40} \mathrm{Ar}$ の大気への脱 ガス，(5) 惑星内部の泠却過程（熱史）に基づくマントル の平均温度, 熱流量, メルト生産率, 脱ガス率などの時 間変化の推定などを考虑したモデルを用い，現在の大気 中の ${ }^{40} \mathrm{Ar}$ 量を制約条件とすることで，地球の火成活動 度の推定をすることができる，それによると，地球史を 通じた平均的なマグマ生産率は， $30-46 \mathrm{~km}^{3} / \mathrm{yr}$ 程度で あると結論される [TAJIKA and MATSUI (1993)]。この 值は，現在の海洋底生産率 $20 \mathrm{~km}^{3} / \mathrm{yr}$ とほぼ同程度で ある。したがって，地球の火成活動及び脱ガス史は，平 均すると現在の 2 倍程度の穞やかなものであったこと か，大気中の ${ }^{40} \mathrm{Ar}$ の量から示唆されるのである.

以下では，さまざまな希ガスのデー夕をむとにして， 京じ地球型惑星である金星と火星の進化について考察を 行なう。 §2では，金星と火星の希ガスについてこれま
で得られているデー夕を紹介する。 そして放射性起源の 希ガス ${ }^{40} \mathrm{Ar}$ と $\left.{ }^{129} \mathrm{Xe}\right)$ の固体質量に対する相対存在度 を見積むる． § 3 および 84 では，それぞれ金星と火星 について, 大気中の ${ }^{40} \mathrm{Ar}$ の現在量之, 過去 ${ }^{40} \mathrm{Ar}$ の放出 を担ってきた火成活動を比較した．本研究のように，火 山活動度や噴出物の量と大気中の ${ }^{40} \mathrm{Ar}$ 量の惑星史にお ける変遷を, 定量的に結びつける試みは，これまで行な われていない. ${ }^{129} \mathrm{Xe}$ のデー夕のある火星では, 放射性 起源の ${ }^{40} \mathrm{Ar}$ と ${ }^{129} \mathrm{Xe}$ の意味するものとして，2 段階の 脱ガスモデルを考えて，地球と比較した．85 では，む

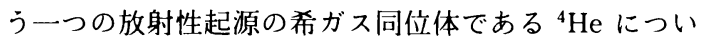
て述べる. 火星では ${ }^{4} \mathrm{He}$ の検知は現在の火成活動の証 拠になりうる. 金星大気の大量の ${ }^{4} \mathrm{He}$ は, 散逸機構とし ての磁場の存在を制約できる可能性がある.

\section{§2. 金星, 火星の希ガス}

\section{1 データソース}

金星では, Pioneer Venus と Venera 11,12 号の着陸 船の質量分析器とガスクロマトグラフから希ガスのデー 夕が得られた．鰵くべきことに，地球と比較すると金星 の ${ }^{36} \mathrm{Ar}$ は 70 倍, ${ }^{20} \mathrm{Ne}$ は 30 倍富んでいる. $\mathrm{Kr}, \mathrm{Xe} に$ ついては, データの不確定さがあるが地球の量の数倍程 度である. Ar- $\mathrm{Kr}-\mathrm{Xe}$ の希ガスの存在度パターンは, “solar"-type と呼ばれる太陽組成に近い隕石の存在度パ ターンに似ている，そのため，金星の希ガスはソーラー ネブラ組成の原始大気が残ったか, 原材料物質への太陽 風照射を強く受けていた，という可能性が高い，比較的

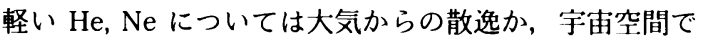
の原材料物質からの逃散で少なくなったと考えられる.

火星では, Viking 1, 2 号の着陸船が火星大気の希ガス の存在度を測定した。 また，火星から来たとされる SNC 隕石の一部の希ガスの組成は, Viking で得られたデー 夕とよく一致する. Viking では $\mathrm{Kr}, \mathrm{Xe}$ の同位体は全部 は得られていないため, SNC 隕石の希ガスのデータも 火星のデー夕として使われている．特に，南極で発見さ

Table 1. Noble gas data of the CI chondrite, Earth, Venus and Mars.

\begin{tabular}{clllll}
\hline \hline & \multicolumn{5}{c}{ Relative abundance (kilogram/kilogram-planet) } \\
\cline { 2 - 6 } & \multicolumn{1}{c}{${ }^{4} \mathrm{He}$} & \multicolumn{1}{c}{${ }^{20} \mathrm{Ne}$} & ${ }^{36} \mathrm{Ar}$ & ${ }^{84} \mathrm{Kr}$ & ${ }^{130} \mathrm{Xe}$ \\
\hline CI & - & $2.89 \times 10^{-10}$ & $1.25 \times 10^{-9}$ & $3.57 \times 10^{-11}$ & $7.0 \times 10^{-12}$ \\
& & \pm 0.77 & \pm 0.10 & \pm 0.15 & \pm 1.9 \\
Earth & $6.21 \times 10^{-10}$ & $1.00 \times 10^{-11}$ & $3.45 \times 10^{-11}$ & $1.66 \times 10^{-12}$ & $1.40 \times 10^{-14}$ \\
& \pm 0.07 & \pm 0.01 & \pm 0.01 & \pm 0.02 & \pm 0.02 \\
Venus & $1.1 \times 10^{-10}$ & $2.9 \times 10^{-10}$ & $2.51 \times 10^{-9}$ & $4.7 \times 10^{-12}$ & $8.9 \times 10^{-14}$ \\
& $+2 /-0.5$ & \pm 1.3 & \pm 0.97 & $+0.6 /-3.4$ & $+2.5 /-6.8$ \\
Mars & $?$ & $4.38 \times 10^{-14}$ & $2.16 \times 10^{-13}$ & $1.76 \times 10^{-14}$ & $2.08 \times 10^{-16}$ \\
& & \pm 0.74 & \pm 0.55 & \pm 0.28 & \pm 0.41 \\
\hline
\end{tabular}


れた shergottite EETA79001 のガラス質のノジュール 中のガスは, 隕石を放出したときの衝突メルトが火星大 気を取り込んだものとされ，Viking のデータを補完す るものとされる [PEPIN (1991)]. この論文でとりあつか う ${ }^{129} \mathrm{Xe}$ と ${ }^{40} \mathrm{Ar}$ については, Viking のデータと火星大 気を取り込んだと考えられる SNC 隕石のデータはよく 合っている. 火星大気の放射性起源でない希ガスの存在 度は, 地球と同様な “planetary”と呼ばれるパターンを 示すが，固体惑星に対する相対量は地球のわずか $1 / 100$ である.

Table 1 は, 主にPEPIN (1991) によりまとめられた, 金星, 火星の希ガスのデータである. CI 隕石, 地球, 大 気中の希ガス X の存在度を, 惑星質量に対する相対存 在度 $\mathrm{R}(\mathrm{X})(\mathrm{kg} / \mathrm{kg})$ で示すと, 惑星間の比較ができる. 例

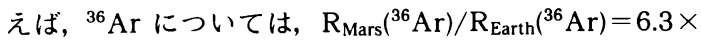
$10^{-3}, \mathrm{R}_{\text {Venus }}\left({ }^{36} \mathrm{Ar}\right) / \mathrm{R}_{\text {Earth }}\left({ }^{36} \mathrm{Ar}\right)=70$ である.

\section{2 放射性起源の希ガスの存在度}

Table 2 に, 放射壊変で生じる希ガス同位体 ${ }^{40} \mathrm{Ar}$ と ${ }^{129} \mathrm{Xe}$ の非放射起源同位体に対する同位体比をまとめ た. ${ }^{129} \mathrm{I}$ は $1.7 \times 10^{7}$ 年という短い半減期で ${ }^{129} \mathrm{Xe}$ に壊変

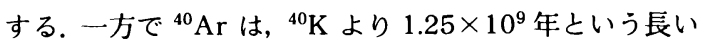
半減期で生じる.この 2 つ同位体を, 天体内部からの 脱ガスの指標として，進化を議論することができる．ま た, ${ }^{4} \mathrm{He}$ は U, Th からの壊変で生産される. ${ }^{4} \mathrm{He}$ のデー 夕の意味についてもあとで考える. 一方, ${ }^{244} \mathrm{Pu}$ の崩壊 で ${ }^{131-136} \mathrm{Xe}$ が生成されるが，Uからの寄与の分離が難 しく正確な議論には使いにくい. 火星大気そのものの同 位体のデータが得られていないこともあり，ここでは取 り扱わない.

金星では大気中の ${ }^{40} \mathrm{Ar}$ の相対存在度は $3.0 \times 10^{-9}$ $\mathrm{kg} / \mathrm{kg}$ で, 地球と比較すると $\mathrm{R}_{\text {venus }}\left({ }^{40} \mathrm{Ar}\right) / \mathrm{R}_{\text {Earth }}\left({ }^{40} \mathrm{Ar}\right)=$ 0.26 である. ${ }^{40} \mathrm{~K}$ の崩壊でできた放射性起源の ${ }^{40} \mathrm{Ar}$ は, 金星では地球の約 $1 / 4$ であり，これは ${ }^{36} \mathrm{Ar}$ とは大きく 異なる。放射性起源でない ${ }^{40} \mathrm{Ar}$ は, 太陽存在度から, ${ }^{40} \mathrm{Ar} /{ }^{36} \mathrm{Ar}=3 \times 10^{-4}$ と見積もられる [ANDERS and GREvESSE (1989)]. 現在の金星大気では ${ }^{40} \mathrm{Ar} /{ }^{36} \mathrm{Ar}=1.2$ で あるから, 非放射性起源の ${ }^{40} \mathrm{Ar}$ は放射性起源の ${ }^{40} \mathrm{Ar}$ の 4000 分の 1 しかなく, 地球と同様に金星でも無視する ことができる. 金星では ${ }^{129} \mathrm{Xe}$ は確認されていない. そ
もそも Xe の存在度の推定が不確定性の高い状況であ る. また大気中の He についてはPioneer Venusなどに よる観測からかなり存在することがわかっており， $\mathrm{R}_{\text {Venus }}\left({ }^{4} \mathrm{He}\right) / \mathrm{R}_{\text {Earth }}\left({ }^{4} \mathrm{He}\right)=200$ である.

火星では, ${ }^{40} \mathrm{Ar}$ の相対存在度について Viking $(5.7 \times$ $\left.10^{-10}\right)$ とEETA79001 $\left(4.9 \times 10^{-10}\right)$ で近い值が求められ る. 地球と比較するとEETA 79001 では $\mathrm{R}_{\text {Mars }}\left({ }^{40} \mathrm{Ar}\right) /$ $\mathrm{R}_{\mathrm{Earth}}\left({ }^{40} \mathrm{Ar}\right.$ ) $=0.048$ (Viking では 0.056) である. 火星 の ${ }^{40} \mathrm{Ar}$ は地球そして金星と比較するとかなり少ないこ とがわかる. Viking の質量分析計は火星の ${ }^{129} \mathrm{Xe}$ が他 の Xe に比べて非常に多いことを観測した。これは SNC 隕石でも確認された。 しかし全ての ${ }^{129} \mathrm{Xe}$ が天体内部で 崩壊した ${ }^{129} \mathrm{I}$ からのものではない. Xe の同位体組成に ついて，放射性起源の寄与や質量分別効果などを取り除 いた成分 U-Xe が提唱されている [PEPIN and PHINNEY (1978)]. 質量分別の効果は考慮して U-Xe との比較で地 球の Xe の同位体組成（大気の值は ${ }^{129} \mathrm{Xe} /{ }^{130} \mathrm{Xe}=6.50 ）$ を考える. 地球の ${ }^{129} \mathrm{Xe}$ のうち放射性起源のものは $6.7 \%$ で ${ }^{129} \mathrm{Xe}^{*} /{ }^{130} \mathrm{Xe}=0.44$, 残りつまり初期值として 考えられるものは ${ }^{129} \mathrm{Xe} /{ }^{130} \mathrm{Xe}=6.06$ である. 火星の $\mathrm{Xe}$ 同位体も地球と同じ初期值であったと仮定する.火 星の同位体組成 (EETA79001: ${ }^{129} \mathrm{Xe} /{ }^{130} \mathrm{Xe}=16.4$ ) から この初期値を引いたものを, 火星の放射性起源の ${ }^{129} \mathrm{Xe}$ を表すものと考える $\left({ }^{129} \mathrm{Xe}^{*} /{ }^{130} \mathrm{Xe}=10.34\right)$. よって放射 性 ${ }^{129} \mathrm{Xe}$ の相対存在度として, 地球との比較では, $\mathrm{R}_{\text {Mars }}$ $\left({ }^{129} \mathrm{Xe}\right) / \mathrm{R}_{\mathrm{Earth}}\left({ }^{129} \mathrm{Xe}\right)=0.35$ を得る. 火星の ${ }^{129} \mathrm{I}$ からの ${ }^{129} \mathrm{Xe}$ は地球に比べると $1 / 3$ であるが, ${ }^{40} \mathrm{Ar}$ との比較か ら言えば ${ }^{129} \mathrm{Xe}$ の存在度は高いといえる. 火星の He に ついてはViking では検知されていないが，紫外領域の 大気光の観測が試みられている.これについては \$5 で 述べたい.

\section{§3. 金星の進化}

\section{1 金星大気中の $\mathrm{Ar}$ がもたらす情報}

金星大気は約 90 気圧の二酸化炭素大気であり，その 組成も地球のもの之は非常に異なっている，しかしなが ら, 地球大気から生物起源の酸素を除き, 堆積岩中に含 まれる炭素を二酸化炭素として大気中に戻してやると (ざっと 60-80 気圧に相当), 両惑星の大気は量的にも

Table 2. Isotopic ratios of radiogenic noble gases in the atmospheres of the Earth, Venus and Mars.

\begin{tabular}{lllcc}
\hline \hline & & ${ }^{40} \mathrm{Ar} /{ }^{36} \mathrm{Ar}$ & ${ }^{129} \mathrm{Xe} /{ }^{130} \mathrm{Xe}$ & ${ }^{129} \mathrm{Xe} /{ }^{132} \mathrm{Xe}$ \\
\hline Earth & & 295.5 & 6.50 & 0.983 \\
Venus & 1.2 & - & - \\
Mars & Viking & $3.01 \times 10^{3}$ & - & $1.5-4.5$ \\
& EETA79001 & $2.26 \times 10^{3}$ & $16.40 \pm 0.8$ & $2.39 \pm 0.03$ \\
\hline
\end{tabular}


質的にも驚くほど似ている。このことは，金星む地球も 间じような材料物質から同じようなプロセスを経て形成 され，したがって同じような原始大気が形成されたにも かかわらず，その後の両惑星の進化の違いによって現在 みられるような異なる大気環境が生じたということを示 唆している. 地球と金星の大気の形成や進化(すなわち 脱ガス史) の違いについてのより詳しい情報は，大気の 希ガス成分を調べることによって得ることができる.

金星大気には, ${ }^{36} \mathrm{Ar}$ が地球の 70 倍む存在する ( $\mathrm{R}_{\mathrm{Venus}}$ $\left.\left({ }^{36} \mathrm{Ar}\right) / \mathrm{R}_{\mathrm{Earth}}\left({ }^{36} \mathrm{Ar}\right)=70\right)$. このことは, 地球の脱ガスの程 度が金星よりずっと低かったことを意味するものではな い. というのは, 地球における ${ }^{36} \mathrm{Ar}$ は, 地球形成時から 数億年以内にその大部分が脱ガスしてしまったと考えら れるので [HAMANO and OzIMA (1978)]，この違いは両惑 星の初期脱ガスの程度の違いを反映しているものではな いといえる.むしろこのことは，金星の材料物質中には もともと地球よりも多量の ${ }^{36} \mathrm{Ar}$ が含まれていたか，ま たは, 地球大気中の ${ }^{36} \mathrm{Ar}$ は初めは金星大気並に存在し ていたが地球史のかなり早い時期に何らかのプロセス (たとえば月の起源と考えられているジャイアントイン パクトなよ゙）によって散逸してしまった可能性を示唆し ている.

一方，金星大気における ${ }^{40} \mathrm{Ar}$ は地球の 0.26 倍しか存 在していない $\left(\mathrm{R}_{\text {Venus }}\left({ }^{40} \mathrm{Ar}\right) / \mathrm{R}_{\text {Earth }}\left({ }^{40} \mathrm{Ar}\right)=0.26\right) .{ }^{40} \mathrm{Ar}$ は ${ }^{40} \mathrm{~K}$ の放射壊変によって生成されるので, この違いは惑 星進化を通じた火成活動度の違いを反映していると解釈 できる．金星より地球の方がずっと活動的で火成活動も 激しかった結果，惑星史を通じて大気中に脱ガスしてき た ${ }^{40} \mathrm{Ar}$ 量が多いのであると考えられる. 大雑把にいう ならば，むしも金星の $\mathrm{K}$ 存在度が地球と同じであると 仮定すれば，金星の火成活動度は地球の約 $1 / 4$ 程度で あったと推定できる．地球史を通じた平均的なマグマ生 産率は, 30-46 km³ $/ \mathrm{yr}$ 程度と推定されているので [TAJikA and MATSUi (1993)], 金星の場合はその約 1/4 として，およそ $10 \mathrm{~km}^{3} / \mathrm{yr}$ 程度と見積もることができ る.

\section{$3.2{ }^{40} \mathrm{Ar}$ の脱ガスモテル}

金星内部からの脱ガス過程は，基本的には地球と同じ であると考えられる．すなわち，金星内部におけるマグ マの生成に伴いメルトへ濃集してきた揮発性成分が，地 表におけるマグマの噴出の際に大気中へ脱ガスしてくる というものである.

前述のように, ${ }^{40} \mathrm{Ar}$ の脱ガスモデルを用いて地球の 平均的な火成活動度について制約することができる [TAJIKA and MATSUI (1993)]. そこで，金星についても 问様なモデルを立ててみる，ただし簡単のために，金星
では地球のようなプレートテクトニクスは機能せず，金 星史を通じてホットスポット的な火成活動が支配してい たと仮定する. また，金星における $\mathrm{K}$ の存在度は地球に おける推定值 (260 ppm, 理論的な上限と下限は 100 ppm-400 ppm) をそのまま質量でスケーリングして使 うことにする.

ポテンシャル温度 $T_{\mathrm{P}}(\mathrm{K})$ のマントル物質（プリュー ムのようなものを想定する）が断熱的に上昇し，減圧に よってマグマ生成が起こると仮定する，上昇してくるマ ントル物質の体積速度 $F_{\mathrm{v}}\left(\mathrm{km}^{3} / \mathrm{yr}\right)$ をパラメータにと る. 実際のメルト生成率は, $F_{\mathrm{v}}$ にメルトフラクション $X$ をかけたものであり，Xはポテンシャル温度から McKENZIE の手法 [MCKENZIE (1984), McKenZIE and BICKLE (1988)] を用いて推定する. マントル中における ${ }^{40} \mathrm{~K}$ の放射壊変による ${ }^{40} \mathrm{Ar}$ の生成と, そのメルトへの 濃集を考慮する。 マントルの全体積を $V_{M}$, マントル中 の ${ }^{40} \mathrm{Ar}$ 量を $\left({ }^{40} \mathrm{Ar}\right)_{M}$ とすれば, ${ }^{40} \mathrm{Ar}$ の脱ガス率 $F_{D}$ は,

$$
F_{D}=f\left(X\left(T_{P}\right)\right) \frac{F_{V}}{V_{M}}\left({ }^{40} \mathrm{Ar}\right)_{M}
$$

と表される（均質マントルを仮定する）。ここで, $f$ は単 位時間当たりに上昇してくるプリュームの体積 $F_{V}$ に含 まれている ${ }^{40} \mathrm{Ar}$ のうち, メルト及び気泡に濃集するこ とによって最終的に脱ガスするものの割合を表す．具体 的には,

$$
f=\frac{1}{1+\frac{\left(X^{-1}-1\right) K^{S / L}}{1+w^{G} / w^{L}}}
$$

ここで, $K^{\mathrm{S} / \mathrm{L}}$ は分配係数, $w^{\mathrm{G}} / w^{\mathrm{L}}$ はメルトへの溶解度 を表す項である [TAJIKA and MATSUI (1992)]. ArやK の場合, $f$ はほぼ 1 に近い值である（それぞれ 0.93, 0.99 と推定される [TAJIKA and MATsul (1993)]). また, マ ントルの温度変化は金星の熱史を計算することによって 推定する.

結果を Fig. 1 に示す. 金星大気中の ${ }^{40} \mathrm{Ar}$ 量 $(=1.4 \times$ $\left.10^{16} \mathrm{~kg}\right)$ を脱ガスさせるために必要な平均的なマグマ噴 出率は，パラメー夕 $F_{V}$ を動かすことにより（解はそれ に対応して図の点線に沿って動く), 約 $5 \mathrm{~km}^{3} / \mathrm{yr}$ であ ることがわかる.この結果は, $\mathrm{R}_{\text {Venus }}\left({ }^{40} \mathrm{Ar}\right) / \mathrm{R}_{\text {Earth }}\left({ }^{40} \mathrm{Ar}\right)=$ 0.26 ということから大雑把に推定した値よりも小さい. その理由は，次のように考えられる． ${ }^{40} \mathrm{Ar}$ の脱ガス率 は, ${ }^{40} \mathrm{~K}$ の放射壊変によって ${ }^{40} \mathrm{Ar}$ が時間的に増加（正 確には，大気へ脱ガスした分を差し引いたマントル中の ${ }^{40} \mathrm{Ar}$ 量が変化）する効果と, マグマ噴出率が惑星内部の 冷却に伴って時間的に減少してくる効果とによって決 まっている．ここで ${ }^{40} \mathrm{Ar}$ の総脱ガス量は, 画者の変化 の仕方の兼ね合い，すなわちそれらを掛け合わせたもの 


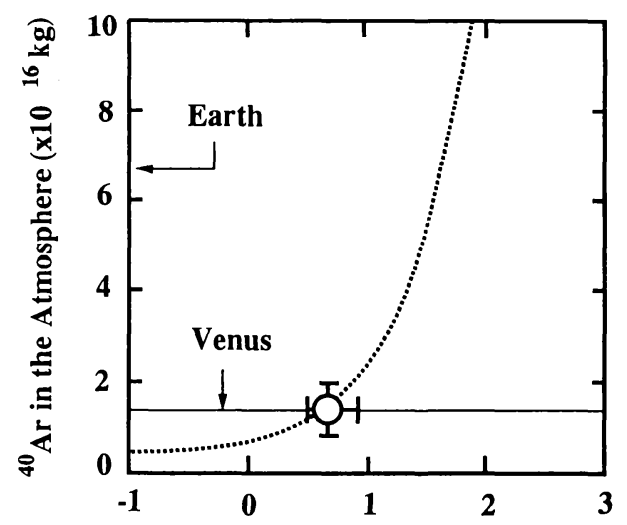

$\log$ (Average Magma Eruption Rate (km $\left.{ }^{3} / \mathbf{y r}\right)$ )

Fig. 1. Amount of ${ }^{40} \mathrm{Ar}$ degassed to the atmosphere as a function of average magma eruption rate over the history of Venus, estimated from ${ }^{40} \mathrm{Ar}$ degassing model by changing a parameter $F_{V}$ (=the volume flux of mantle material ascending to the surface). Horizontal line represents the observed value of ${ }^{40} \mathrm{Ar}$ in the present atmosphere of Venus.

の時間積分として決まるため, 必ずし屯平均的なマグマ 噴出率には比例しないのである（マントル中の被脱ガス 成分の量が常に一定の場合に限り，その脱ガス総量は平 均的マグマ噴出率に比例する). さらに, マグマ噴出率が 小さくなれば, その分マントル中により多くの ${ }^{40} \mathrm{Ar}$ が 残る. したがって, 特定の ${ }^{40} \mathrm{Ar}$ 量を脱ガスさせるため にはマグマ噴出率自体はより小さくなる必要がある. 一 方, 地球モデルの場合は大陸地殼中に多量の $\mathrm{K}$ が濃集 することを考虑している結果, マントル中の ${ }^{40} \mathrm{Ar}$ 生産 量は金星モデルの方が相対的に多くなり，やはりマグマ 噴出率自体はより小さくなる必要がある.こうした理由 により, ${ }^{40} \mathrm{Ar}$ 脱ガスモデルから推定された金星におけ る平均マグマ噴出率は, 地球と金星の大気中における ${ }^{40} \mathrm{Ar}$ の存在度から単純に推定されたものより小さく なっている. 金星における平均マグマ噴出率は, 地球の 場合と比べて 1/6-1/9 という規模に相当する.

\section{3 金星にプレート画勒はあったか?}

過去の金星において, 地球のようなプレートテクトニ クスが機能していたのかどうか, 機能していたとして, それがどのような規模のものであったのかについては全 く不明である.ここでは, 地球史における平均的なマグ マ生産率が現在とあまり変わらないという推定結果 [TAJIKA and MATSUI (1993)] を考え合わせ, 金星におい ても地球と同じ規模の火成活動を伴うような“地球型プ レートテクトニクス”が機能していたと仮定した場合

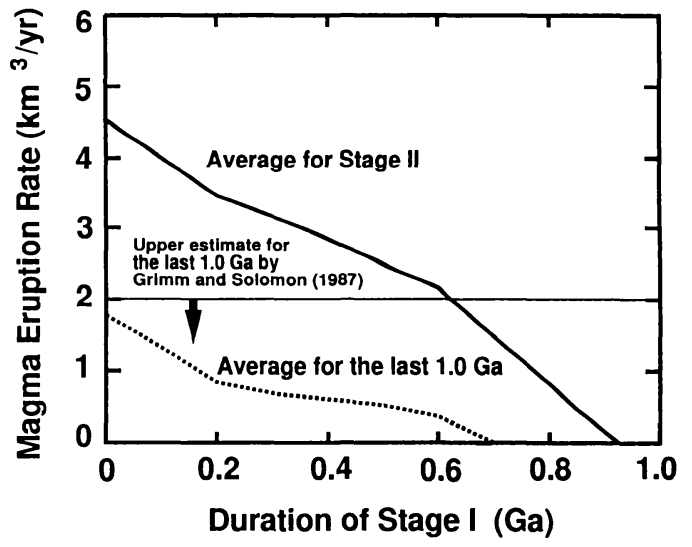

Fig. 2. Average magma eruption rates estimated from ${ }^{40} \mathrm{Ar}$ degassing model of Venus. Solid line represents the magma eruption rate averaged over the Stage II $(\tau$ $<t<4.6 \mathrm{Ga}$ : the period in which hot spot type volcanism is dominant), as a function of duration of Stage I $(0<t<\tau$. the period in which plate tectonics is dominant). Dotted line represents the magma eruption rate averaged for the last $1.0 \mathrm{Ga}$ of the model calculation. Horizontal line represents its upper bound estimated from crater statistics on Venus by GRImm and Solomon (1987).

に，その継続時間はどのくらいであるかについての簡単 な推定を行なう.

いま仮に，過去の金星において地球型のプレートテク トニクスが機能していたと考えてみる.それがある時刻 $\mathrm{t}$ において停止し，現在のようなホットスポット的な火

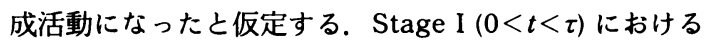
マグマ噴出率は現在の地球のものと同じと仮定し, Stage II $(\tau<t<4.6 \mathrm{Ga})$ においては, 前述のモデルを用 いることにする.

その結果を Fig. 2 に示す. 金星大気中の ${ }^{40} \mathrm{Ar}$ 存在量 を脱ガスさせるために必要な Stage II における平均的 なマグマ噴出率を, Stage I の継続時間 $\mathrm{t}$ の関数として 表しておる. $t=0$ の場合における平均マグマ噴出率は約 $5 \mathrm{~km}^{3} / \mathrm{yr}$ であるが, これはプレート運動が全く起こら なかったとする場合（前述のモデル）の結果に対応して いる. Stage I の継続時間, すなわちプレート運動の継続 時間 $\mathrm{t}$ が長くなると，その分 Stage I における ${ }^{40} \mathrm{Ar} の$ 脱ガス量が增加し, 後に続く Stage II の脱ガスの寄与 (すなわち火成活動度) は小さくならなければならい.プ レート運動が約 10 億年も継続すると, 現在観測されて いる金星大気中の ${ }^{40} \mathrm{Ar}$ 量は全てこの時期に脱ガスして しまう結果となり，その後は脱ガスを伴う火成活動はほ 
とんど全く起こらなかったことになってしまう。このこ とは, 次に述べる観測事実と矛盾する。したがって, た 之元原始金星において地球規模の火成活動を伴うょうな “地球型プレートテクトニクス”が起こったとしても，そ の継続時間はたかだか数億年以下程度であろうことが示 唆される.しかしながら，ここでの議論はもちろん，金 星におけるプレート運動が地球とは異なり,ずっと小規 模の火成活動しか伴わないという場合に対する制約には なっていないことに注意する必要がある.

\section{4 金星の火成活勤}

米国の惑星探查機 Magellan による金星表面の詳細な 観測の結果, 金星の地表にはクレーターが非常に少な く, そこから推定される地表の年齢は 5 億年程度である ことが分かった [SoLOMON (1993)]. 地球の場合, 地表の $70 \%$ 占める海洋底の平均年齢は約 $60.4 \mathrm{Ma}$ であるか らこの值は地球と比べて古いともいえるが, 現在の金星 では地球型のプレート運動が確認されていないことを考 えると，むしろこの値は驚くほど若いというべきもので ある. 金星ではごく最近まで（あるいは現在において も), 金星の全表面を更新するような大規模な, しかも地 球のプレート運動とは異なったタイプの火成活動（たと えば洪水玄部岩の噴出など）が起こっている可能性が高 い. さらに, 金星表面の年代分布を調べるとほとんどが 5 檍年付近に集中しており, 地表面の更新は連続的とい うよりもむしろエピソディック [SCHABER et al. (1992)] またはカタストロフィック [PHILLIPS et al. (1992)] であ るらしい.

金星表面には古い情報は残されていないから，金星の 歴史を通じた火成活動度を推定することは, 地球の場合 之同様に観測的には不可能である. しかし, 最近数億年 の火成活動度を推定することは可能である．そのような 試みが, 間接的にではあるが, クレーター生成率と火成 活動によるその消失率の関係に注目することにより理論 的な観点から行なわれている [BulLock et al. (1993), Grimm and Solomon (1987)]. Grimm and Solomon (1987) は, カタストロフィックな地表面の更新は考え ず, Venera 15, 16 号によって観測された金星表面のク レーター分布を制約条件とし, 衝突によるクレーター生 成率と連続的なマグマ噴出によるクレーター消失率との 兼和合いから，過去数億年間の地表面更新率の上限は 2 $\mathrm{km}^{3} / \mathrm{yr}$ であると推定した. また, BuLLOCK et al. (1993) は, Magellan の観測によるクレーター密度と形態（溶 岩流によって部分的に埋め立てられているかどうかな ど）などの情報をもとに，モンテカルロ法を用いて同様 の推定を行ない, 上述の観測データを説明するために は, カタストロフィックな地表面更新以降 $0.37 \mathrm{~km}^{3} / \mathrm{yr}$
の連続的なマグマ噴出が必要であることを示した。

一方, カタストロフィックなマグマ噴出がどの程度の 規模であるかは不明であるが，たとえば全表面を厚さ 1 $\mathrm{km}$ 程度覆うようなマグマ噴出 (100 km 程度のクレー ターを埋めることができる）があったとしてそれを 10 億年平均してみると, 約 $0.46 \mathrm{~km}^{3} / \mathrm{yr}$ となる.これが, カタストロフィックなマグマ噴出を平均した場合のおよ その下限值であると考えることができる.したがって, 過去 5 億年間のマグマ噴出率は $0.37 \mathrm{~km}^{3} / \mathrm{yr}$ 程度, 過 去 10 億年平均では, カタストロフィック・イベントの 規模によるので正確なところは分からないが，おそらく 1-2 $\mathrm{km}^{3} / \mathrm{yr}$ 程度であろうと考えられる.

そこで, 前述の計算において過去 10 億年間のマグマ 噴出率の平均をとったものを Fig. 2 の点線で示す. ただ し，この計算では連続的な火成活動を考えているので, カタストロフィックなイベントの影響はならされてし まっていることに注意する（しかしながら、マントル中 の ${ }^{40} \mathrm{Ar}$ 量がだいたい一定とみなせる時間スケールの範 囲では，火成活動が連続的でもカタストロフィックでも 脱ガスに対する影響は小さいはずである). $\tau=0$ の場合 でも, 過去 10 億年の平均的なマグマ噴出率は $2 \mathrm{~km}^{3} / \mathrm{yr}$ 以下であることが分かる.この結果は, GRIMM and Solomon (1987) の推定と調和的である. 46 億年間の平 均値に比べて過去 10 億年平均の值が小さくなる理由 は, 金星内部温度の時間的低下に伴ってメルト生産率も 低下するためである. BuLLOCK et al. (1993) の推定結果 はこれよりさらに小さい值であるが，カタストロフィッ ク・イベントを考慮することにより，そのような小さな 值も説明可能である.

このように，大気中の ${ }^{40} \mathrm{Ar}$ の存在量から，過去の金 星において仮に地球規模の火成活動を伴うプレートテク トニクスが機能していたとしてもその継続期間はたかだ か数億年以内であり, 金星史の大部分を通じての火成活 動度は地球の 1/6-1/9 以下であったと考えられる. 金 星における火成活動が, 地球に比べて弱いとはいえごく 最近まで継続しているということは，大気進化を考える 上で重要であろう.

\section{§4. 火星の進化}

\section{1 火星の火山体の体樌と ${ }^{40} \mathbf{A r}$}

Mariner 9 号と Viking 1,2 号の撮像により火星全面 の画像が得られている. 火星には巨大な楯状火山が存在 して, 火山性の平原も存在する. 経度 90 度から 150 度 にわたるタルシス高原 (Tharsis)・オリンポス山 (Olympus Mons)・アルバパテラ (Alba Patera) の広い地域や, 経度 210 度付近のエリシウム高原 (Elysium) が代表的 
で，大部分の火山は火星の北半球に集中している.

表面のクレーターの数密度から, 火山体の形成時期を 推定することができる. クレーター密度が小さいほど年 代は新しい，月での衝突・クレーター形成の頻度のモデ ルを灭星に外挿することで絶対年代のモデルも立てるこ とができる. Fig. 3 は火山噴出物の量と絶対年代との対 応である. 噴出物の量については, GREELEY (1987) およ び GREELEY and SCHNEID (1991) の見積もりを使い，ク レーター年代のモデルは TANAKA et al. (1992) にある 2 通りのものを用いた. HT (HARTMANN and TANAKA) モ デルでは火山活動は古い時代に激しかったことになり, NW (NEWKUM and WISE) モデルでは比較的最近まで火 山活動が継続的であるということになる.

火星には海嶺などプレートテクトニクスの直接の証拠 はない，初期には衝突やマグマオーシャンからの脱ガス が起きたかもしれないが，火星の歴史の大部分を通じて の脱ガスの担い手は残っている火山であろう。この章で はまず，火星大気に現存する ${ }^{40} \mathrm{Ar}$ の量之火山体の噴出 から見積もられる ${ }^{40} \mathrm{Ar}$ の量を比較して検討をしたい.

地球では, 未分化マントルの ${ }^{40} \mathrm{~K}$ の存在度を現在の値 で $5.0 \times 10^{-8} \mathrm{~kg} / \mathrm{kg}$ とすると, 現存すべき ${ }^{40} \mathrm{Ar}$ は 6.2 $\times 10^{-8} \mathrm{~kg} / \mathrm{kg}$ になる.この值は現在の大気中の ${ }^{40} \mathrm{Ar}$ 量 $\left(1.0 \times 10^{-8} \mathrm{~kg} / \mathrm{kg}\right)$ の 6 倍である. つまり地球でも脱ガ スしていない ${ }^{40} \mathrm{Ar}$ がかなり存在する. 火星では $\mathrm{K}$ の存 在度を地球と同じとすると, 大気中の ${ }^{40} \operatorname{Ar}\left(5.7 \times 10^{-10}\right.$ $\mathrm{kg} / \mathrm{kg})$ は, ${ }^{40} \mathrm{~K}$ が崩壊して生成されたものの $1 \% に し$

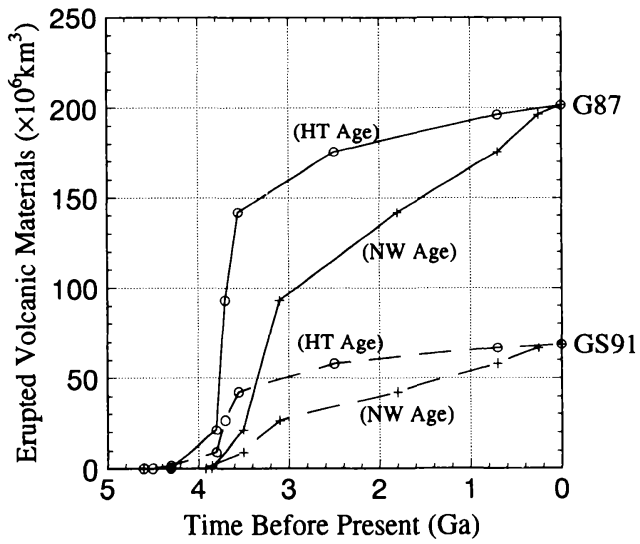

Fig. 3. Martian volcanic materials estimated by the present surface volcanics. Erupted volume during each epoch was estimated by GreEley (1987) (denoted by G87) or GREELEY and Schneid (1991) (denoted by GS91). Absolute ages are estimated from surface crater density. We use two models: HT [HARTMANN et al. (1981) and TANAKA (1986)] and NW [NEUKUM and WISE (1976)].
か過ぎないことがわかる．激しい衝突時代が終了した後 は, ${ }^{40} \mathrm{Ar}$ を火星大気から散逸させるのは難しい. 少ない ${ }^{40} \mathrm{Ar}$ は, 内部からの脱ガスが少なかったことを直接示 している.

Fig. 3 のモデルに従って, 火星内部からのマグマの噴 出に伴う脱ガスを考える. 火山内部のマグマの生成に伴 いメルトに濃集した揮発性成分がマグマとともに上昇・ 噴出すると考える. 金星の場合と異なり, 簡単なモデル を使って噴出量のデータからマグマ量を逆算することに する．ここで，地表近くまで到達したが表面に噴出して いないマグマからの寄与の部分をパラメータを使って導 入する。 $\eta$ は上昇したマグマのうち表面に噴出して火山 体を形成した割合である. $1-\eta$ は火星の表層下で固化 した部分に相当する. また，マグマは部分溶融で供給さ れるから， ${ }^{40} \mathrm{Ar}$ を集める領域の総体積は噴出するマグ マの体積より大きくなるはずである．源の ${ }^{40} \mathrm{Ar}$ 濃度と マグマの ${ }^{40} \mathrm{Ar}$ 濃度の比を $\xi=\mathrm{C}_{\mathrm{Ar}} / \mathrm{C}_{\mathrm{Ar} \text {-melt }}$ よする.する とマグマの噴出率を $q$ とすれば, ${ }^{40} \mathrm{Ar}$ の脱ガス速度は $\mathrm{C}_{\mathrm{Ar}} q / \eta \xi$ と書ける. Fig. 3 の $q$ を使い火星内部の ${ }^{40} \mathrm{Ar}$ 濃度の時間変化を入れて, 時間で積分することで, 大気 中へ供給された ${ }^{40} \mathrm{Ar}$ の総量を求めることが可能であ

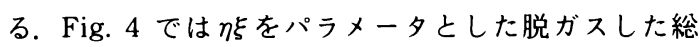
${ }^{40} \mathrm{Ar}$ 量を描いた。 現在の火星大気の ${ }^{40} \mathrm{Ar}$ 量に対応する $\eta \xi$ の値は 0.02-0.06である.

パラメータ $\xi$ は部分溶融度と固液間の $\mathrm{Ar}$ の分配係数

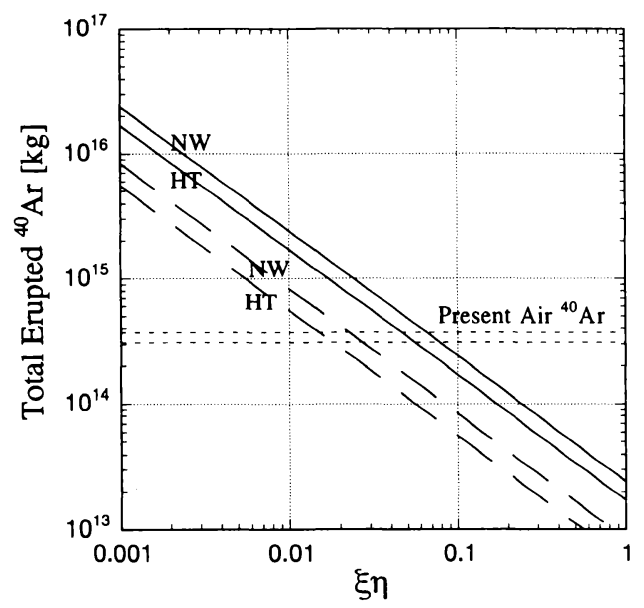

Fig. 4. Total degassed ${ }^{40} \mathrm{Ar}$ for different values of $\xi \eta$. Solid lines are based on volume estimate by Greeley (1987). Dashed lines are based on volume estimate by GREELEY and Schneid (1991). NW denotes the age model by NeUKum and WISE (1976) and HT denotes the age model by HARTMANN et al. (1981) and TANAKA (1986). 
で表現できる．とくにArが非常に incompatible（結晶 よりメルトに濃集しやすい)なら $\xi$ は部分溶融度にな る. 実験的に求められている $\mathrm{Ar}$ の分配係数は $D_{\text {solid/mel }}$ 〜0.1 [HIYAgoN and OzIMA (1986)] である.この場合, 部分溶融度が低い $(\ll 0.1)$ と分配係数が $\xi$ を決める. 実 際のマグマの上昇では，数\%溶融するとメルトが抜けて いく分別融解 (fractional melting) を起こすので, 単な る部分溶融度だけで $\xi$ 表すことはできない. McKeNZIE and O'NION (1991) は, 噴出物の希土類元素の濃集度 から逆に内部の部分溶融状態を求めた． Ar が内部で希 土類と同様に incompatibleにふるまうと考えると，希 土類元素の濃集度から $\xi$ を求めることができる．地球の 海嶺玄武岩では 0.10 , 八ワイのソレアイト玄武岩では 0.05 程度の值である．また，噴出しなかったマグマを取 り入れるパラメータクとしては GREELEY and SCHNEID (1991) は 1/9.5 に相当する値を使っている. しかし場所 によっては標高 26-27 km にも達する火星の火山体の 下にその 10 倍近いマグマ岩体が存在するとは考えにく い. $\eta$ として 1/2〜1/4 程度を考えると， $\eta \xi$ は Fig. 4 か ら期待される現在の火星の ${ }^{40} \mathrm{Ar}$ を説明する值になる。

\section{$4.2{ }^{129} \mathrm{Xe}$ と ${ }^{40} \mathrm{Ar}$ の 2 段階脱ガスモデル}

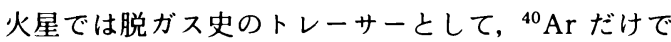
はなく ${ }^{129} \mathrm{Xe}$ を使うことができる，両者が与える情報を はっきりさせるために，簡単な 2 段階脱ガスモデルを考 える. $\lambda_{129}, \lambda_{40}$ をそれぞれ ${ }^{129} \mathrm{I} ，{ }^{40} \mathrm{~K}$ の壊変定数とする. ここで, $t_{1}\left(\lambda_{129} t_{1} \geq 1, \lambda_{40} t_{1} \ll 1\right), t_{2}\left(\lambda_{40} t_{2} \sim 1\right)$ を脱ガスの時 間とする. $t_{1}$ での内部のガスの脱ガスの割合を $\alpha, t_{2}$ では $\beta$ と仮定する. 実際は $\alpha, \beta$ とも脱ガスする成分による違 いはないとする． $\alpha, \beta$ の大きさに極端な違いがない場 合, 大気へ出た放射性起源の ${ }^{129} \mathrm{Xe},{ }^{40} \mathrm{Ar}$ の総量は

$$
\begin{aligned}
& { }^{129} \mathrm{Xe}^{*}=\alpha^{129} \mathrm{I}_{0}\left(1-\exp \left(-\lambda_{129} t_{1}\right)\right) \\
& +\beta\left[(1-\alpha){ }^{129} \mathrm{I}_{0}\left(1-\exp \left(-\lambda_{129} t_{1}\right)\right)\right. \\
& \left.+{ }^{129} \mathrm{I}_{0}\left(\exp \left(-\lambda_{129} t_{1}\right)-\exp \left(-\lambda_{129} t_{2}\right)\right)\right] \\
& \approx \alpha^{129} \mathrm{I}_{0}\left(1-\exp \left(-\lambda_{129} t_{1}\right)\right) \\
& { }^{40} \mathrm{Ar}^{*}=\alpha f_{\mathrm{Ar}^{40}} \mathrm{~K}_{0}\left(1-\exp \left(-\lambda_{40} t_{1}\right)\right) \\
& +\beta[1-\alpha) f_{\mathrm{Ar}^{40}} \mathrm{~K}_{0}\left(1-\exp \left(-\lambda_{40} t_{1}\right)\right) \\
& \left.+f_{\mathrm{Ar}}{ }^{40} \mathrm{~K}_{0}\left(\exp \left(-\lambda_{40} t_{1}\right)-\exp \left(-\lambda_{40} t_{2}\right)\right)\right] \\
& \approx \beta f_{\mathrm{Ar}}{ }^{40} \mathrm{~K}_{0}\left(\exp \left(-\lambda_{40} t_{1}\right)-\exp \left(-\lambda_{40} t_{2}\right)\right) \\
& \approx \beta f_{\mathrm{Ar}^{40}} \mathrm{~K}_{0}\left(1-\exp \left(-\lambda_{40} t_{2}\right)\right)
\end{aligned}
$$

と書ける. $f_{\mathrm{Ar}}=0.1048$ は ${ }^{40} \mathrm{~K}$ のうち ${ }^{40} \mathrm{Ar}$ に崩壊する 割合である. ${ }^{129} \mathrm{I},{ }^{40} \mathrm{~K}$ の初期存在度 ${ }^{129} \mathrm{I}_{0},{ }^{40} \mathrm{~K}_{0}$ が地球と 火星とで同じで，脱ガスの時期もほぼ同じであるとする と，上の式を使って結局

$$
\frac{\mathrm{R}\left({ }^{129} \mathrm{Xe}^{*}\right)_{\text {Mars }}}{\left.\mathrm{R}^{(129} \mathrm{Xe}^{*}\right)_{\text {Earth }}} \approx \frac{\alpha_{\text {Mars }}\left(1-\exp \left(-\lambda_{129} t_{\mathrm{M} 1}\right)\right)}{\alpha_{\text {Earh }}\left(1-\exp \left(-\lambda_{129} t_{\mathrm{E} 1}\right)\right)}
$$

$$
\begin{aligned}
& \approx \frac{\alpha_{\text {Mars }}}{\alpha_{\text {Earth }}}=0.35 \\
& \frac{\mathrm{R}\left({ }^{40} \mathrm{Ar}^{*}\right)_{\text {Mars }}}{\mathrm{R}\left({ }^{40} \mathrm{Ar}^{*}\right)_{\text {Earth }}} \approx \frac{\beta_{\text {Mars }}\left(1-\exp \left(-\lambda_{40} t_{\mathrm{M} 2}\right)\right)}{\beta_{\text {Earth }}\left(1-\exp \left(-\lambda_{40} t_{\mathrm{E} 2}\right)\right)} \\
& \approx \frac{\beta_{\text {Mars }}}{\beta_{\text {Earth }}}=0.048
\end{aligned}
$$

となる，放射性の希ガス量の相対的な違いは，脱ガスの 割合の違いを表すことになる。この結果は，脱ガスの次 期が $t_{1} \sim 10^{8} \mathrm{yr}$ (a few $10^{7} \mathrm{yr} \sim \mathrm{a}$ few $10^{8} \mathrm{yr}$ ), $t_{2} \geq 10^{9} \mathrm{yr}$ で ある限り, 地球と火星との間で $t_{1}, t_{2}$ にいくらか違いが ある場合も, 後の脱ガスが連続的なものである場合も, 変わることはない. $t=t_{2}$ で記述される後の脱ガスは, 地 球より火星では弱く, 相対的に約 $1 / 20$ であった。 $t=t_{1}$ のときの初期の脱ガスは, 火星は地球の $1 / 3$ であるがそ の違いは後の脱ガスほど大きくはない.むしろ地球と火 星で近いともいえる.

現在の火星大気中の ${ }^{40} \mathrm{Ar}$ の量から見積もられる, 後 の脱ガス度は $\beta_{\text {Mars }} \sim 0.01$ で 1 よりはるかに小さい，そ のため, 初期の脱ガス度が大きく $\left(\alpha_{\text {Mars }} \geq 0.1\right)$, 脱ガスの 時期が $t_{1} \geqq 10^{8} \mathrm{yr}$ であると, $t=t_{1}$ のときの初期脱ガスで 大気へ出た ${ }^{40} \mathrm{Ar}$ の量が, 後の火山活動で脱ガスした量 と同程度になる.ただし(5) より $\alpha_{\text {Mars }}<0.35$ であるた め, 初期に脱ガスした ${ }^{40} \mathrm{Ar}$ は極端に多くはならず, 噴 出物と脱アルゴン量を結びつけるパラメータ $\eta, \xi$ の不確 定さの範井内で説明することは十分可能である.

\section{3 火星史における脱ガス}

この結果を火星の進化と照らし合わせて考えてみる. 惑星初期の脱ガスの機構として, 集積の時の衝突脱ガス とマグマオーシャンからの脱ガスが考えられる. まず, $t=t_{1}$ での ${ }^{129} \mathrm{Xe}$ を放出した脱ガスについて, 惑星集積 のときの衝突脱ガスが原因と考えることは可能だろう か. 例えば地球の場合, OzIMA and IGARASHI (1989) は, 初期脱ガスを衝突脱ガスによるものと考えた。

しかし, 集積段階では, 脱ガス大気でも原始大気は若 い太陽の強い紫外線で動力学的に散逸する可能性が高 い，さらに，衝突そのものも揮発性成分を供給するだけ ではなく，大気をはぎ取る効果があり [MeLOSH and VICKERY (1989), WALKER (1986)], 特に重力の小さい火 星ではこの効果は無視できない，そのため集積中には大 気が安定に存在できるかどうか難しく, 大気の残存量で は地球と火星との間に大きな差ができてもおかしくな い，実際には，火星では放射性起源でない希ガスの量が 地球よりも 2 桁低く, 衝突脱ガスと大気の散逸はむし ろ，これを説明する機構と考えるべきであろう (Fig. 5a) [ZAHNLE (1993)].

集積段階の地球・火星とも，微惑星の衝突による重力 


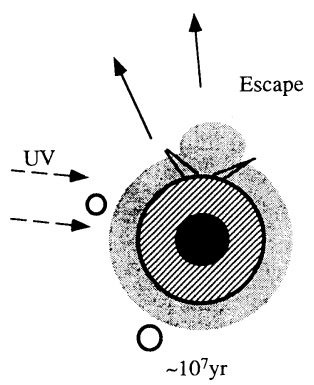

(a)

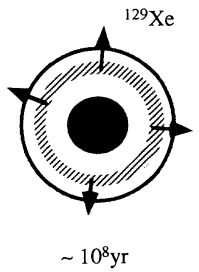

(b)

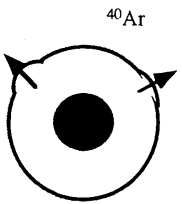

$\sim 10^{9} \mathrm{yr} \sim$ Present

(c)

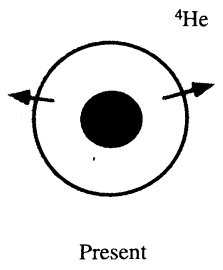

(d)

Fig. 5. Martian degassing and atmospheric evolution. (a) Accretional stage: impact degassing should supply volatiles. But the protoatmosphere is escaped by huge impact (atmospheric cratering) or by hydrodynamic escape due to strong ultraviolet irradiation from the protosun. (b) Magma ocean cooling stage: volatiles are accumulated into residual melts and finally outgassed from the interior. A large fraction of decayed ${ }^{129} \mathrm{Xe}$ degassed at this moment. (c) Volcanic activities: magmatic activities forming large volcanoes should have continued during Martian history. Erupted volume is compatible with degassed ${ }^{40} \mathrm{Ar}$. (d) Current degassing: precise detection of atmospheric ${ }^{4} \mathrm{He}$ will be indirect evidence for the current activities.

エネルギーの解放之原始大気の保温効果により少なくと あ $1500 \mathrm{~K}$ 程度には温度が上昇した。 マグマオーシャン が形成されて，鉄・シリケイト分離（この過程む重力エ ネルギーを解放して熱源となる）が進行して中心核は集 積とほぼ同時にできたと考えられる，集積が止んで原始 大気の保温効果む停止すると，マグマオーシャンは冷却 をはじめ, $10^{8}$ 年の時間で固化していく $[\mathrm{ABE}(1993)]$. 揮発性成分は残った液相に濃縮して最後に噴出をする. ${ }^{129} \mathrm{Xe}$ を放出した機構として，マグマオーシャンの冷却 に伴う脱ガスは有力である (Fig. 5b). また $\alpha_{\text {Mars }} / \alpha_{\text {Earth }}$ $1 / 3$ という結論は, マグマオーシャンの冷却に伴う脱ガ スが地球でも火星でも似たような規模で起きたことを示 唆するが，衝突脱ガスの場合と異なりこれを否定する大 きな理由はない。

一方で, $t=t_{2}$ に対応する脱ガスは, 火星史を通じての 火山活動と考えることができる (Fig. 5c). ${ }^{40} \mathrm{Ar}$ の噴出 量は現在の火山体の体積からの見積むり之矛盾しない. 火山活動は長期間に渡るから, これを単純な $t=t_{2}$ での 事件とするのは極端な近似である。しかし，地球との対 照で脱ガスの割合を比較する場合においては問題はな い. 地球と火星の ${ }^{40} \mathrm{Ar}$ の違いは, 地球と金星の差と同 様に，惑星の活動度の違いを表している，火星には全球 的なプレートテクトニクスは無く（最近，北極域の平原 はプレート活動の跡であるという説がある [SLEEP, 1994])，ホットスポット的な大火山による供給がほとん ごの ${ }^{40} \mathrm{Ar}$ の脱ガスを担っていたのだろう. 4.1 で述べた ように現在の火山噴出物の量は, 少ない脱ガス量を反映 した火星大気中の ${ }^{40} \mathrm{Ar}$ の量と調和的である.

\section{§5. ヘリウム}

放射性起源の希ガスとして, ${ }^{238} \mathrm{U},{ }^{235} \mathrm{U},{ }^{232} \mathrm{Th}$ の放射 壊変の過程で生じる ${ }^{4} \mathrm{He}$ む存在する。これを火星・金 星の火成活動や進化の制約条件に使う可能性をここでは 考えたい.

\section{1 火星}

Viking の着陸船に搭載された質量分析器は火星大気 の Heを検知することはできなかった [NIER and MCElroy (1977)]. 1993年 1 月, KrASNOPOLSKy et al (1993) は，極紫外線衛星 (EUVE: Extreme Ultraviolet Explorer) で火星を観測し，He の $58.4 \mathrm{~nm}$ の共鳴散乱 光を測定した. その結果, 大気光として $43 \pm 10 \mathrm{R}(1 \mathrm{R}=$ $10^{6}$ photons $\left./ \mathrm{cm}^{2}\right)$ を得た。これは上層大気の $\mathrm{He}$ の量 として $1.1 \pm 0.4 \mathrm{ppm}$ に相当する.

重い ${ }^{40} \mathrm{Ar},{ }^{129} \mathrm{Xe}$ と異なり, ${ }^{4} \mathrm{He}$ は大気加ら散逸する ことが可能なため, 現在の量は長期間の脱ガスを必ずし あ反映しない. 地球では, He は極域の磁力線を伝って 極風 (polar wind) として散逸すると考えられていて [AXFORD (1968)], 極軌道衛星による流出の観測屯存在 する [ABE et al. (1993)]. 存在量と供給量のバランスか ら求められる大気中の ${ }^{4} \mathrm{He}$ の滞在時間は $10^{6}$ 年で, 地 球の年歯よりはるかに短い. 地球では, 大気の ${ }^{4} \mathrm{He} の$ $20 \%$ が中央海嶺の火山活動に伴って放出・供給され，大 部分 (70\%) はもともとU, Th に富んだ大陸地殼からの 寄与であると考えられている [TORGERSON (1989)]. 海 嶺からの $\mathrm{He}$ は $10^{6}$ 年という時間内では連続的に供給さ れているであろう。しかし，地壳の岩石内の $\mathrm{He}$ の拡散 速度はおそく, マグマの移動や地下水の循環などの機構 
が脱ガスに重要な役割を果たしているはずである [ToRGERSON (1989)].

火星では磁場が無いか非常に弱いため極風による $\mathrm{He}$ 散逸は働かないが, 重力が弱いため $\mathrm{He}$ 帯在時間は地球 より短い（ $10^{5}$ 年）と考えられている [KRASNOPOLSKY et al. (1993)]. そのため火星大気中の He が存在するな らば, 現在火星内部からの脱ガスが進行中であることを 意味する. KRASNOPOLSKY et al. (1993) は, 定常的な脱 ガスを仮定して, ${ }^{4} \mathrm{He}$ の量から火星の地殼の U, Th の存 在度がわかると推論した。 彼らの欠点は, 何が脱ガスの 過程かどうかは考えていないことにある. 火星では, 地 球の中央海嶺のような連続的な源は存在しない. 火星大 気の $\mathrm{He}$ の存在は, 地殼からの脱ガス過程が現在も継続 していること,つまり, 火成活動や水循環などが火星表 層下で進行していることの証拠になるであろう (Fig. 5 d). これまでの火星の観測では, 現在の流水活動や火山 活動の証拠はない. クレーター密度から, 少なくとも十 億年内に火山活動があったことはわかる程度である.

$\mathrm{He}$ の検知は, 現在の火星の地殼内部の活動を間接的に でも示す貴重なデータになるだろう。むろん隕石の衝突 により地域的な脱ガスが起こり，蓄えられていた Heが 放出されるという可能性がある. しかし, 大きなクレー ターを作る数 $\mathrm{km}$ サイズの天体の衝突間隔は, $10^{6}$ 年よ りはるかに長く, 定常的な He 源とは考えにくい.

火星の He の確認のためには，もっと精度の高い観測 が必要である. EUVEの観測では, 火星そのものが画像 の 1 ピクセル以下で雑音レベルが高い. 宇宙科学研究所 が 1998 年に打ち上げる予定の PLANET-Bに, He の $58.4 \mathrm{~nm}$ を観測する極紫外観測器を搭載する予定である [NAKAMURA et al. (1994)].この観測が成功すれば, 火星 上層大気の $\mathrm{He}$ の存否について詳細なデータが得られる はずである.

\section{2 金星}

金星の大気中の $\mathrm{He}$ の存在度は高い. 地球と比較する と $\mathrm{R}_{\text {venus }}\left({ }^{4} \mathrm{He}\right) / \mathrm{R}_{\text {Earth }}\left({ }^{4} \mathrm{He}\right)=200$ である. この比は $\mathrm{Ne}$, $\mathrm{Ar}$ より大きい. 金星大気が形成時に始原的な ${ }^{4} \mathrm{He}$ を取 り込んだと考えられるだろうか. しかし，現在の金星に は固有磁場が存在せず, 効果的に $\mathrm{He}$ を逃がすことはで きない. ${ }^{40} \mathrm{Ar}$ の金星と地球の量比 $\left(\mathrm{R}_{\mathrm{Venus}}\left({ }^{40} \mathrm{Ar}\right) / \mathrm{R}_{\text {Earth }}\right.$ $\left.\left({ }^{40} \mathrm{Ar}\right)=0.26\right)$ を単純に $\mathrm{He}$ の天体内部からの脱ガス量の 違いに置き換えると, 金星大気での $\mathrm{He}$ の滞在時間は, $10^{6}$ 年 (地球での值) $\times 200 / 0.26 \sim 8 \times 10^{8}$ 年と見積もら れる.これは金星の年踚よりは短いため, 始原的な ${ }^{4} \mathrm{He}$ の寄与がなくても内部からの放射性起源 ${ }^{4} \mathrm{He}$ の脱ガス で金星大気の ${ }^{4} \mathrm{He}$ 量は説明することができる.

しかし一方で, He を逃がす機構が全く無いならば,
内部から放出された ${ }^{4} \mathrm{He}$ は大気に蓄積される。見積も られる $\mathrm{He}$ の滞在時間ははるかに長く，金星の年齢程度 になるはずである，そのためこの金星の He 量は，磁場 がここ数億年存在しないことを反映しているが，過去に は有効に $\mathrm{He}$ を逃がしていた，つまり磁場が存在してい たことも否定していないことになる.

\section{謝 辞}

本稿は, 1993 年秋に岡山大学地球内部研究センター で開かれたシンポジゥムの話の一部を土台にまとめたも のである. シンポジゥムを企画され，本稿を書く機会を 与えていただいた佐藤博樹氏に感謝いたします。また， 長尾敬介氏，五十嵐丈二氏の查読に感謝いたします。本 研究の一部には, 文部省科学研究費補助金・重点領域研 究「マグマの発生と挙動」(No. 05231103) および総合研 究「デジタル画像情報を用いた比較惑星地質学の総合的 研究」(No. 05302026) を使用しました。

\section{文献}

AвE, Y., 1993, Thermal evolution and chemical differentiation of the terrestrial magma ocean. In Evolution of the Earth and Planets. (ed. E. Takahashi, R. Jeanloz and D. Rubie), pp. 41-54. AGU.

Abe, T., B. A. Whalen, A. W. Yan, R. E. Horita, S. WATANABE and E. SAgawa, 1993, EXOS D (Akebono) suprathermal mass spectrometer observations of th polar wind, J. Geophys. Res., 98, 1119111203.

Allègre. C. J., T. Staudacher and P. Sarda, 1987, Rare gas systematics: Formation of atmosphere, evolution and structure of the earth's mantle. Earth Planet. Sci. Lett., 81, 127-150.

Anders, E. and N. Grevesse, 1989, Abundances of the elements: Meteoritic and solar, Geochim. Cosmochim. Acta, 53, 197-214.

AxFord, W. I., 1968, The polar wind and the terrestrial helium budget, J. Geophys. Res., 73, 6855-6859.

Brown H., 1952, Rare gases and formation of the Earth's atmosphere. In The Atmospheres of the Earth and Planets. (Kuiper G. P. ed.), 2nd ed., pp. 258-266, University of Chicago Press, Chicago.

Bullock, M. A., D. H. Grinspoon and J. W. Head III, 1993, Venus resurfacing rates: Constraints provided by 3-D Monte Carlo simulations. Geophys. Res. Lett., 20, 2147-2150.

GREeLEy, R., 1987, Release of juvenile water on Mars: Estimated amounts and timing associated with volcanism. Science, 236, 1653-1654.

Greeley, R. and B. D. Schneid., 1991, Magma generation on Mars: Amounts, rates, and comparisons with Earth, moon, and Venus. Science, 254, 996998. 
Grimm, R. E. and S.C. Solomon, 1987, Limits on modes of lithospheric heat transport on Venus from impact crater density. Geophys. Res. Lett., 14, 538-541.

Hamano, Y. and M. Ozima, 1978, Earth-atmosphere evolution model based on Ar isotopic data. In: Terrestrial Rare Gases (ed. E. C. Alexander Jr. and M. Ozima), pp. 155-171, Japan Scientific Society Press.

Hartmann, W. K., R. G. Strom, S. J. Weidenschilling, K. R. Blasius, A. Woronow, M. R. Dence, R. A. F. Grieve, J. Diaz, C. R. Chapman, E. N. Shoemaker and K. L. JonEs, 1981, Chronology of planetary volcanism by comparative studies of planetary cratering. In Basaltic Volcanism on the Terrestrial Planets. 1049-1127, Pergamon.

Hiy agon, H. and M. Ozima, 1986, Partition of noble gases between olivine and basalt melt. Geochim. Cosmochim. Acta, 50, 2045-2057.

Hunten, D. M., R. O. Pepin and J. C. G. Walker, 1987, Mass fractionation in hydrodynamic escape. Icarus, 69, 532-549.

Krasnoplosky, V. A., S. Chakrabarti and G. R. GladSTONE, 1993, Helium in the Martian atmosphere. J. Geophys. Res., 98, 15061-15068.

Lange, M. A. and T. J. Ahrens, 1982a, The evolution of an impact-generated atmosphere. Icarus, 51, 96120.

LAnge, M. A. and T. J. Ahrens, 1982b, Impact induced dehydration of serpentine and the evolution of planetary atmospheres. Proc. 13th Lunar Planet. Sci. Conf., J. Geophys. Res., 87 Supple., A451-A456.

McKenZIE, D., 1984, The generation and composition of partially molten rock. J. Petrol., 25, 713-765.

McKenziE, D. and M. J. BickLE, 1988, The volume and composition of melt generated by extension of the lithosphere. J. Petrol., 29, 625-679.

McKenzie, D. and R.K. O'Nions, 1991, Partial melt distributions from inversion of rare earth element concentrations. J. Petrol., 32, 1021-1091.

Melosh, H. J. and A. M. ViCKery, 1989, Impact erosion of the primordial Martian atmosphere. Nature, 338, 487-489.

Nakamura, M., T. Yamamoto, K. Tsuruda, Y. Saito, K. Yamashita, A. Furuzawa, T. Ogawa and S. ChaKRABARTI, 1994, Interplanetary He II Extreme Ultra Violet Observation on PLANET-B. submitted to Optical Engineering.

Neukum, G. and D. U. Wise, 1976, Mars: A standard crater curve and possible new time scale. Science, 194, 1381-1387.

Nier, A. O. and M. B. McElroy, 1977, Composition and structure of Mars' upper atmosphere: Results from the neutral mass spectrometers on Viking 1 and 2. J. Geophys. Res., 82, 4341-4349.

Ozima, M. and G. Igarashi, 1989, Terrestrial noble gases: Constraints and implications on atmospheric evolution. In Origin and evolution of planetary and satellite atmospheres. (ed. S. K. Atreya, J. B. Pollack and M. S. Matthews), 306-327. Univ. Arizona Press.

PEPIN, R. O., 1991, On the origin and early evolution of terrestrial planet atmospheres and meteoritic volatiles. Icarus, 92, 2-79.

Pepin, R. O. and D. Phinney, 1978, Component of xenon in the solar system. (preprint)

Phillips, R. J., R. F. Raubertas, R. E. Arvidson, I. C. SARKAR, R. R. Herrick, N. IzEnBerg and R. E. GRIMM, 1992, Impact craters and Venus resurfacing history. J. Geophys. Res., 97, 15923-15948.

Rubey, W., 1951, Geologic history of sea water, an attempt to state the problem. Bull. Geol. Soc. Am., 62, 1111-1148.

Schaber, G. G., R. G. Strom, H. J. Moore, L. A. Solomon, R. L. Kirk, D. J. Chadwick, D. D. Dawson, L. R. GAdDIS, J. M. Boyce and J. Russel., 1992, Geology and distribution of impact craters on Venus: What are they telling us? J. Geophys. Res., 97, 1325713301.

Sleep, N. H., 1994, Martian plate tectonics, J. Geophys. Res., 99, 5639-5656.

Solomon, S. C., 1993, Keeping that youthful look. Nature, 361, 114-115.

Staudacher, T. and C. J. Allk̀gre, 1982, Terrestrial Xenology. Earth Planet. Sci. Lett., 60, 389-406.

TAjik A, E. and T. Matsui, 1992, Evolution of Terrestrial Proto- $\mathrm{CO}_{2}$-Atmosphere Coupled with Thermal History of the Earth. Earth Planet. Sci. Lett., 113, 251-266.

TAJikA, E. and T. MAtsui, 1993, Evolution of seafloor spreading rate based on ${ }^{40} \mathrm{Ar}$ degassing history. Geophys. Res. Lett., 20, 851-854.

TANAKA, K. L., 1986, The stratigraphy of Mars. Proc. Lunar Planet. Sci. Conf. 17, J. Geophys. Res. Suppl., 91, E139-E158.

TANAKA, K. L., D. H. Scott and R. GReEley, 1992, Global Stratigraphy. In Mars. (ed. H. H. Kieffer, B. M. Jakosky, C. W. Snyder and M. S. Matthews), 345-382. Univ. Arizona Press

Torgerson, T., 1989, Terrestrial helium degassing fluxes and the atmospheric helium budget: Implications with respect to the degassing processes of continental crust. Chemical Geology, 79, 1-14.

Turcotte, D. L. and G. Schubert, 1988, Tectonic implications of radiogenic noble gases in planetary atmospheres, Icarus, 74, 36-46.

W ALker, J. C. G., 1986, Impact erosion of planetary atmospheres. Icarus, 68, 87-98.

ZaHnle, K. J., 1993, Xenological constraints on the impact erosion of the early Martial atmosphere. J. Geophys. Res., 98, 10899-10913. 